\title{
PARTAI GERINDRA DALAM KONTESTASI PERPOLITIKAN DI BALI TAHUN 2008 - 2019
}

\author{
Jerico Siahaan ${ }^{1}$ \\ I Putu Gede Suwitha ${ }^{2}$ \\ Anak Agung Inten Asmariati ${ }^{3}$ \\ 1,2,3 Program Studi Ilmu Sejarah \\ Fakultas Ilmu Budaya, Universitas Udayana \\ siahaanjerico8@gmail.com; putu_suwitha@yahoo.co.id; inten_asmariati@unud.ac.id
}

\begin{abstract}
ABSTRAK
Studi ini akan mengambil tema Sejarah Politik dengan topik "Partai Gerindra Dalam Kontestasi Perpolitikan di Bali, Tahun 2008 - 2019." Studi akan melihat bagaimana Partai Gerindra yang bernafaskan "Nasionalis - Kerakyatan" ini dapat berkontestasi secara politik di Bali, Adapun rumusan masalah yang akan dibahas sebagai berikut. (1). Bagaimana kiprah partai Gerindra di Bali dalam Pemilu (2). Mengapa terjadi Kontestasi Politik partai Gerindra dalam Pemilu di Bali. (3). Apa implikasi kehadiran Partai Gerindra dalam Kontestasi Politik di Bali. Kemudian Metodelogi yang penulis gunakan dalam penulisan ini adalah sejarah politik, sosial, dan yang terakhir pemikiran. Hasil penelitian ini menunjukkan kehadiran Gerindra pada tahun 2008, dan juga keikutsertaan - nya di dalam perhelatan politik 2009 tingkat nasional dan pada tingkat provinsi telah memberikan corak politik yang bernuansa semangat nasionalisme ke dalam perpolitikan di Indonesia khusus - nya di Bali. Kerja keras yang dibangun dalam visi dan misi partai berlambang kepala Garuda ini, telah menancapkan akar - nya hingga dapat dikenal masyarkat Bali. Program kampanye partai Gerindra dinilai bagian dari prioritas permasalahan negara saat ini. Gerindra akan selalu berkontestasi membela kepentingan rakyat demi menciptakan kesejahteraan hidup masyarakat banyak. Keberhasilan Gerindra dalam meningkatkan elektabilitas partai pada pemilu 2009, 2014 dan 2019 telah memberikan antuasiame publik yang begitu besar, Gerindra mampu menunjukkan eksistensi nya kedalam perhelatan politik tahunan di pilkada maupun tingkat legislatif, Gerindra juga mampu menampung aspirasi masyarakat mengenai isu - isu perekonomian yang berlandasakan pariwisata sebagai sektor pengembangan bagi kemajuan masyarakat di Bali. Dalam menata kembali komodifikasi politik di Bali, Gerindra juga berupaya melihat peta politik daerah mana saja di Bali sebagai nilai dan fokus kemenangan para calon yang diusung oleh Gerindra. Berbicara mengenai implikasi Gerindra yang mampu memberikan potensi terhadap sektor pengembangan politik, sosial maupun hukum, 11 tahun kontribusi tersebut dibangun oleh Gerindra untuk mentransformasikan tingkat kepercayaan masyarakat terhadap keberlangsungan partai Gerindra di Bali, baik di tingkat kota dan daerah kabupaten provinsi.
\end{abstract}

Kata Kunci: Partai Gerindra, Kontestasi, Nasional - Kerakyaatan, Kader anggota partai, Bali.

\begin{abstract}
This study will take the theme of Political History with the topic "Gerindra Party in Political Contest in Bali, 2008 - 2019." In this paper, the research proposal that the author adopts, namely the Gerindra Party which has a" Nationalist - Democratic "breath can contest politically in Bali, as for the problems that will be disclosed as follows: (1). How do the Gerindra party in Bali play in the General Election; (2). Why is there a Gerindra party political contestation in the elections in Bali; (3). What are the implications of the Gerindra Party in the Political Contest in Bali. Then the methodology that the author uses in this writing is political history, social history, and finally the history of thought. The results of this study indicate that the presence of Gerindra in 2008, and also its participation in the 2009 political events at the national and provincial levels, has provided a political style with a spirit of nationalism in politics in Indonesia, especially in Bali. The hard work
\end{abstract}


built into the vision and mission of the party bearing the head of the Garuda, has planted its roots so that it can be recognized by the Balinese people. The programs campaigned by Gerindra are considered to be included in the priority problems of the country at this time. Gerindra is a party with a platform, Nationalist - Popular. Why? The proof that Gerindra gives to the community is that Gerindra will always compete in defending the interests of the people in order to create the welfare of the people at large. Gerindra's success in increasing party electability in the 2009, 2014 and 2019 elections has provided enormous public enthusiasm, Gerindra is able to demonstrate its existence in the annual political events at both the regional elections and the legislative level, Gerindra is also able to accommodate people's aspirations regarding based economic issues. tourism as a development sector for the advancement of society in Bali. In reorganizing political commodification in Bali, Gerindra also seeks to see the political map of any area in Bali as the value and focus of winning Gerindra's candidates. Talking about the implications of Gerindra being able to provide potential for the political, social and legal development sector, 11 years of this contribution was built by Gerindra to transform the level of public trust in the sustainability of the Gerindra party in Bali, both at the city and provincial regency levels.

Keywords: Gerindra Party, Contestation, Nationalist - Democratic, Cadres of party members, Bali.

\section{PENDAHULUAN}

Berbicara tentang Politik di Bali tentu tidak luput dari perhatian publik saat itu, dimana akan dilihat bagaiamana transformasi konflik dalam sistem kepartaian dalam satu wilayah lokal. Pada Pemilihan Umum (Pemilu) yang di - selengarakan pada 1955 di Bali, Partai Nasionalis Indonesia muncul sebagai partai dominan disusul Partai Sosialis Indonesia (PSI), lalu Partai Komunis Indonesia (PKI). Kemunculan Orde Baru dengan Golongan Karyanya secara mencolok mengubah peta politik di Bali.

Secara garis besar, politik berkenaan dengan kekuasaan, pengaruh, kewenangan akan pengaturan, dan ketaatan atau ketertiban. Dengan mengikuti pola diatas, maka baik politik itu sendiri maupun ilmu politik tidaklah selalu harus dalam kaitan dengan negara dan pemerintahan. (Rudy, 1993: 5).

Kehidupan berpolitik di Bali sangat dinamis, jika dilihat secara garis besar kemunculan partai - partai baru dapat mengubah peta politik secara signifikan. Perubahan itu terlihat saat kehadiran Golkar di Buleleng yang telah memberikan arah berbeda dari kebiasaan dan kekuatan politik sebelumnya oleh Partai Nasionalis Indonesia, Partai Sosialis Indonesia, Partai Komunis Indonesia. Orde Baru sukses membangun kekuatan, fondasi dan sistem, sehingga Partai Golkar menjadi mesin politik yang tidak dapat ditawar hampir di seluruh pelosok tanah air. Pemerintah Golkar juga berhasil menjadikan tahun 1966 sebagai awal dimulainya dengan "pelupaan kenangan pahit masa lalu untuk bersama - sama melangkah ke masa depan". Adapun kenangan pahit yang dimaksud, yaitu Komunisme, PKI menjadi barang terlarang dibicarakan. Suara - suara kritis dan kehidupan politik menjauh dari citra Bali. (Surywan, 2012: 104).

Pemilahan Umum merupakan salah satu konsestasi publik. Sistem pemilihan umum merupakan metode yang mengatur serta memungkinkan warga negara memilih atau mencoblos para wakil rakyat. Setidak - nya terdapat dua fungsi sistem pemilahan umum, yaitu konversi suara pemilih (votes) menjadi kursi (seats) penyelengara negara lembaga legislatif dan lembaga eksekutif baik pada tingkat nasional maupun lokal. Kedua, sebagai instrumen untuk membangun sistem politik 
demokrasi, yaitu melalui konsekuensi setiap unsur sistem pemilihan umum terhadap berbagai aspek sistem politik demokrasi. (Nurhanisah \& Putra, 2019).

Penulis ingin melihat bagaimana peran masyarakat Bali luas masuk kedalam ranah politik secara khusus yang terlibat dalam kontestasi politik melalui Partai Gerindra. Berbicara tentang ideologi politik, tidak akan lepas dari pengertian ideologi, bagaimana partai lahir, dasar apakah sebuah partai tersebut dapat hadir di tengah masyarakat, semua hal ini menjadi alasan pilihan masyarakat terhadap partai sebagai sebuah harapan mendapatkan kesejahteraan yang layak di dalam hidupnya.

\section{METODE}

Dalam spesifikasi instrument penelitian ini, akan menjawab sebuah pertanyaan yang berupa sebuah pemahaman politik, khususnya kontestasi perpolitikan partai Gerindra di Bali pada tahun 2008 - 2019. Di sini akan diuraikan tentang jenis dan spesifikasi intrumen yang digunakan berupa tiga tahapan yaitu : (1).Heuristik atau (Pengumpulan data). Herusitik dalam bahasa Yunani yang berarti menemukan dan merupakan kata kerja yang digunakan untuk teknik analisa berbasis pengalaman yang akan membantu penyelesian sebuah masalah. Jadi di dalam herustik penelitian ini akan membantu dalam menganalisis sumber data yang berupa artikel - artikel yang akan memuat pembertiaan tentang partai Gerindra di Bali. (2). Interpretasi atau (yang menetapkan fakta atau makna di dalam penulisan sejarah). Interpretasi merupakan sebuah jalan keluar bagi peneliti untuk dapat memperoleh sumber data yang diperoleh, mulai dari wawancara dan dokumen serta arsip. (3). Historiografi atau (Penulisan Sejarah). Historiografi atau penulisan sejarah merupakan sebuah hasil dari keseluruhan yang berupa rekontruksi akhir dalam tema yang diangkat. Historiografi menjadi sebuah hasil akhir dari peneliti menggambarkan tema yang diangkat.

\section{KERANGKA TEORI}

Marketing Politik, mencoba untuk melakukan perubahan - perubahan di dalam dunia politik dengan tujuan agar dapat mengembalikan dunia politik kepada tujuan semula yaitu menyerap dan mengapresiasikan pendapat masyarakat. Dalam konsep ini penulis ingin melihat bagaimana Partai Gerindra mengambil suara masyrakat di Pemilu Bali, oleh karena itu Teori Marketing Politik O'Cass yang dikutip dari Firmanzah (2012) akan digunakan untuk menampilkan Kontestasi Partai Gerindra memperoleh simpati masyarakat.

\section{HASIL DAN PEMBAHASAN}

\section{Kiprah Partai Gerindra di Bali Dalam Pemilu}

Di Bali pembentukan Dewan Perwakilan Daerah dan Dewan Perwakilan Cabang partai Gerindra berdiri secara bertahap, gedung baru yang selanjutnya menjadi Dewan Perwakilan Daerah yang sekaligus mewakili Provinsi Bali terletak di Jl. Tantular No. 7 ini dibawahi atau dikomandoi oleh Ida Bagus Putu Sukarta menjelaskan pihaknya sengaja memasang foto kedua puluh tiga pahlawan tersebut sebagai spirit perjuangan partai Gerindra. Mereka adalah tokoh penting dalam sejarah perjalanan bangsa ini. Itu menjadi spirit perjuangan kami "jelas Sukarta saat ditemui disela - sela peresmian kantor tersebut. Di Bali Gerindra mampu merebut 
2 kursi, hal ini tentunya membuat banyak partai - partai seperti Hanura, PAN, PKPI dan terkhusus - nya PDI - Perjuangan sebagai partai yang memiliki mayoritas suara terbesar dalam politik di Bali, dapat tertarik melihat Gerindra sebagai partai yang mampu mendompleng suara di dalam pemilu maupun di tingkat pilkada. (Amb 2016).

Pada saat tahun 2008 pemilihan kepala daerah diadakan serentak di seluruh pelosok tanah air, saat itu pula bagaimana partai politik khususnya di Bali menyusun agenda penting dalam menyukseskan pilkada serentak yang diselengarakan oleh Komisi Pemilihan Umum.

Komisi Pemilihan Umum, adalah suatu lembaga yang dipilih dan ditetapkan berdasarkan undang - undang sebagai penyelenggara pemilihan umum, dimana pada awal pembentukannya, KPU merupakan lembaga yang beranggotakan Lembaga Swadaya Masyarakat (LSM). Komisi Pemilihan Umum Daerah (KPUD) merupakan bawahan KPU pusat yang berfungsi untuk menyelenggarakan pemilihan umum secara berjenjang. Penyelenggaran pemilihan kepala daerah di kabupaten atau kota diselenggarakan oleh KPUD. Pelaksanaan pemilihan kepala daerah yang baik, tidak cukup hanya dari kerja KPU, tetapi juga harus diikuti dengan adanya kesadaran dan tingkat partisipasi masyarakat yang tinggi. Tingkat partisipasi masyarakat dipengaruhi oleh bagaiamana lembaga KPUD mengarahkan partisipasi masyarakat, dan tingkat partisipasi masyarakat juga mempengaruhi baik tidaknya hasil perolehan dari penyelenggaran pemilihan umum. (Gito et al., 2013).

Selain itu pilkada yang terlaksanan dengan baik secara menunjukkan ada peningkatan demokrasi. Dimana partisipasi masyarakat dalam pemilihan umum suatu negara menjadi ukuran demokrasi disaat masyarakat ikut berperan dalam menentukan pemimpin. Pilkada langsung dapat memberikan ruang partisipasi rakyat untuk mewujudkan kedaulatan dalam menentukan pemimpin di daerah. Hal ini akan mendorong terwujudnya keseimbangan antara infrastruktur dan suprastruktur politik. Selain itu pelaksanaan pilkada langsung juga sejalan dengan otonomi daerah yaitu pengakuan terhadap aspirasi masyarakat untuk menentukan nasibnya sendiri. Selain melalui pilkada langsung dapat meningkatkan kualitas akuntabilitas para elite politik dan efektivitas pemerintahan daerah. (Hutapea, 2015).

Dalam hal ini Gerindra melihat hal tersebut sebagai peluang untuk menata dan terlibat dalam kontestasi perpolitikan Indonesia, pasalnya dalam pilkada langsung yang berlangsung pada tahun 2008, secara tidak langsung dapat belajar dari pemlihan kepala daerah sebelumnya. Bagaimana politik saat itu tidak bisa terlepas dari keadaan partai Gerindra yang membutuhkan koalisi partai untuk dapat melenggang dalam pemilu di 2009. Pilkada pada tahun 2008 merupakan kesempatan yang dapat memberi peluang besar kepada partai - partai baru, pasalnya seperti Gerindra melihat peluang besar tersebut dengan bergabung di jajaran koalisi politik bersama PDI - P ini menandakan bahwa keseriusan tersebut memang dibangun untuk memajukan citra partai di seluruh lintas masyarakat.

Penjelasan diatas dapat menjelaskan bagaimana elektabilitas partai Gerindra terus meningkat dari tahun ke tahun hal ini menyebabkan partai ini semakin familiar di kalangan masyarakat tanah air, khususnya di Bali. Data pencapaian perolehan partai ini pada tahun 2008 - 2009 menunjukkan fakta dimana partai Gerindra 
mendapatkan perolehan suara yang sangat tinggi, pada saat partai - partai lain mengalami penurunan suara. Dimana partai Gerindra mengalami kenaikan suara yang sangat signifikan dari 4,46 persen menjadi 11,8 persen, jika dikonversikan pada perolehan kursi. Perolehan suara ini menjadi menarik karena partai Gerindra merupakan partai baru dalam politik Indonesia. Partai Gerindra pertama kali mengikuti pemilu pada tahun 2009. Sebagai partai baru, Gerindra berhasil menempati peringkat ke 8 dalam pemilu legislatif 2009 dengan perolehan suara sebanyak 4.646.406 (Nurdiansyah, 2018).

\section{Kontestasi Politik Gerindra Dalam Pemilu}

Pada bagian ini akan membahas tentang kontestasi politik Gerindra dalam pemilu seberapa jauh hubungan yang dibangun oleh Gerindra akan menentukan budaya politik Gerindra. Dalam hal ini sangat relevan kontestasi politik yang Gerindra ciptakan untuk memuluskan langkah birokarasi politik dalam agenda politik tahunan yang akan berlangsung.

Hubungan birokarasi dan budaya politik ini karena ada beberapa sebab : (1) sebagai pengetahuan awal untuk bisa memahami tentang berbagai macam definisi budaya politik, (2) bisa menjelaskan tentang tipe - tipe budaya politik di suatu negara, (3) bisa berpikiran luas bahwa banyak ahli yang mampu melihat dan melakukan pendekatan atas budaya politik. (Martini, 2012). Pada hakikatnya pembentukan partai politik melandaskan pada pemahaman yang telah disusun dan dicita - citakan bersama. Kemudian ideologi menjadi sebuah kendaraan dalam identitas yang menunjukan arah pergerakan sebuah partai. Melihat konteks partai Gerindra dalam memuat arah ideologi dan gagasan yang tercantum dalam visi dan misi yang diemban oleh Gerindra adalah sebagai partai Nasionalis - Kerakyatan.

Secara umum strategi pemasaran politik yang dilakukan partai Gerindra dengan menjadikan figur Prabowo Subianto sebagai brand atau produk politik sebagai produk utama. Hal ini wajar karena konstelasi politik Indonesia masih didominasi oleh kekuatan seorang figur. Dalam tahap segmentasi, targeting, hingga positioning, dapat diperhatikan bahwa figur Prabowo Subianto selalu muncul dan menjadi ujung tombak dari strategi pemasaran yang dilakukan partai Gerindra. (Nurdiansyah, 2018).

Hal yang lain tak kalah penting yaitu bagaimana penentuan orang - orang dalam struktur organisasi partai Gerindra. Diketahui bahwa seseorang harus mendapat persetujuan ketua dewan pembina untuk bisa menduduki jabatan struktural partai. Mekanisme yang dilakukan selalu ada rapat pengurus mulai tingkat desa (Ranting) hingga kabupaten (DPC) untuk mengusung nama calon. (Nico, et al., 2018)

Langkah politik partai Gerindra dalam menysun agenda politik memanglah tidak mudah, diperlukan semangat dan intregritas yang tinggi dari kader hingga anggota partai untuk dapat menyukseskan agenda tahunan politik. Dalam menata langkah perpolitikan, Gerindra saat ini mengetahui sangat mendalam aktifitas politik yang terjadi, bahwa Gerindra akan siap menentukan langkah - langkah politik kepada partai - partai yang mengemban dan visi dan misi yang sesuai dengan Gerindra yaitu mewujudkan kesejahteraan maysarakat yang adil dan makmur. 
Semenjak itulah perjalanan politik antara partai Gerindra dan partai politik lain mengalami kemajuan yang signifikan, ini semua dimaknai dengan silahturahmi antar partisipasi politik baik ditingkat pusat, provinsi hingga di daerah. Di Bali Gerindra memperoleh langkah - langkah yang gemilang, dari banyaknya perhitungan hasil suara yang membuat Gerindra tetap eksis hingga saat ini.

Kontestasi perpolitikan yang terjadi di tubuh partai Gerindra dapat dilihat sebagai arus untuk melihat peluang Gerindra dalam membendol suara. Teater Pemilu dan Pilkada adalah ajang yang sangat ditunggu dalam memetakan konsep masing - masing perolehan suara di beberapa tempat. Seperti Denpasar, Klungkung dan juga Buleleng masih menjadi bobot perolehan suara yang mampu menaikan elektabilitas perolehan suara Gerindra di Bali. Tempat - tempat tersebut masih menjadi arena politik yang diminati oleh Gerindra Bali dalam menyiapkan para kader - kader yang diharap mampu menekan suara Gerindra di masyarakat. salah satu yang menarik adalah kisah para caleg satu keluarga dalam perhelatan Pileg tahun 2014 yang lalu. Yaitu dua saudara yang dikenal akrab sebagai anak politikus dari Nyoman kakak beradik ini mampu memeriahkan perhelatan pentas politik di Buleleng, pasalnya kedua saudara tersebut dapat menarik antusias masyarakat Buleleng dalam meraih suara di tingkat DPRD Bali dapil Buleleng.

Partai Gerindra juga memanfaatkan kader dan calon yang sudah memiliki modal sosial. Bourdieu memandang arena adalah suatu sistem posisi sosial yang terstruktur. (Budianto, 2019: 90). Ini dapat terlihat bagaimana masyarakat Buleleng cenderung memilih calon - calon yang sudah mereka kenal di dapil mereka, dimana Nova dan Agus, keberhasilan keduanya juga tidak lepas dari seorang Nyoman Semer yang mampu memberikan modal sosial dan budaya terhadap kedua - nya. Latar belakang seorang calon atau kader juga tidak bisa lepas dari praktik - praktik yang melekat pada dirinya, keberhasilan tersebut mampu membuat partai - partai terlebih Gerindra untuk melihat kembali calon potensial yang dapat diusung dari berbagai sturuktur, ikatan emosional antara kader dan partai juga menjadi sangat penting untuk meraih simpati masyarakat.

Partai politik bila dilihat dari struktur kalimatnya terdiri dari suku dua kata, yakni "partai" dan "politik". Menurut Firmanzah dunia politik adalah suatu domain aktivitas sosial yang menyangkut terjadinya perebutan dan distrubusi kekuasaan disini dunia politik mempunyai karakteristik sendiri sebagaimana domain aktivitas sosial lainnya.

Meski terkesan memilih kader dengan modal sosial yang tinggi, sejatinya partai politik memiliki kewajiban untuk mencetak kader yang berkualitas, karena nanti kader inilah yang akan menjadi pemimpin bagi semua orang dan elemen masyarakat. Dalam menentukan kadernya untuk mengikuti kepala daerah, partai politik juga tidak boleh asal sembarangan menentukan kader yang menjadi calon. Syarat menjadi calon kepala daerah juga ditentukan oleh partai, dengan memberikan pertimbangan pada kapabilitas, kemampuan di segala bidang baik leadership, yang ketiga tidak terkait kasus korupsi dan hukum yang lain. (Razaqtiar, 2016: $353-357)$.

\section{Implikasi Kehadiran Partai Gerindra Dalam Kontestasi Politik di Bali}


Berkurang dan bertambahnya jumlah partai politik yang terlibat dalam dinamika politik Indonesia tentu membawa dampak yang signifikan bagi kontestasi politik yang sudah ada, begitu juga dengan kehadiran partai Gerindra di Bali. Sebagai bagian dari penataan kehidupan politik ini mempunyai implikasi yang menarik untuk dikaji. Partai - partai yang mulanya berpartisipasi dengan enggan dalam tata politik baru, terus mencari peran yang tepat dalam masyarakat. Semangat kehidupan kepartaian sebagai suatu kelompok yang mempunyai cita - cita dan aspirasi tertentu dan berhadapan dengan kelompok lain - nya, telah mendorong kompetisi walaupun hanya sewaktu pemilu. (Kacung, 1993: 47).

Tingginya angka partisipasi masyarakat Bali dalam pemilu 2019 serentak lalu berbanding lurus dengan indeks demokrasi yang terus meningkat tiap tahun - nya. Badan Pusat Statistik provinsi Bali mencatat, indeks demokrasi provinsi Bali dengan mengukur tiga aspek yaitu kebebasan sipil, hak - hak politik, dan lembaga demokrasi menunjukan angka yang menggembirakan sejak tahun 2014 sampai dengan 2018. (Arjawa, et al., 2019: 23). Bila melihat angka dan partsipasi politik masyarakat terhadap hasil pemilu dan juga hasil pileg diatas, menunjukkan bahwa kepercayaan masyarakat Bali terhadap faktor - faktor pendukung yang mengisi kontes perpolitikan.

Kepuasan atas pelaksanaan kinerja kepimpinan Jokowi menjadi sebuah topik yang dipersoalkan oleh gerakan \#gantipresiden2019. Meskipun hasil survei menampilkan bahwa sebanyak 72,5\% masyarakat puas sedangkan 27,5\% tidak puas dengan kepimimpinan Jokowi yang mengindikasikan bahwa kedudukan Jokowi masih terbilang kuat namun demi mewujudkan pemilu yang berintregritas, tindakan demikian harus dihindari. (Benyamin \& Sudibya, 2019).

Dalam implikasi yang terjadi, partai Gerindra melihat hal tersebut sebagai kewajaran politik, yang mendukung upaya nilai - nilai demokrasi demi menciptakan pemilihan umum yang dapat dinaliai oleh masyarakat sebagai suatu cerminan dalam meneruskan pendidikan politik. Jadi masyarakat dapat dan berhak untuk menentukan platform politik apa yang baik menurut mereka. Dasar dan corak pemilu maupun hasil pileg pada tahun 2019 telah memberikan komunikasi politik yang dirasakan setiap partai mempunyai andil dalam memperebutkan manifestasi politik - nya. Memang hal yang masih belum berubah adalah keberadaan Gerindra di luar pemerintahan. Gerindra masih eksis sebagai partai yang mampu membuktikan dan mengkritik kinerja pemerintah yang dinilai masih kurang dalam memberikan kesejahteraan pada masyarakat.

Gerindra berkomitmen untuk selalu menjadi partai yang memberikan peran kepada masyarakat, di berbagai daerah khusus - nya di Bali, Gerindra akan selalu memberikan kesetian politik - nya terhadap masyarakat, sebagai masyarakat yang berdikari sesuai dengan cita - cita partai.

\section{SIMPULAN}

Kehadiran Gerindra pada tahun 2008, dan keterlibatan partai ini di dalam perhelatan politik 2009 pada tingkat nasional dan pada tingkat provinsi telah memberikan corak politik yang bernuansa semangat nasionalisme ke dalam perpolitikan di Indonesia khusus - nya di Bali. Kerja keras yang dibangun dalam 
visi dan misi partai berlambang kepala Garuda ini, telah menancapkan akar - nya hingga dapat dikenal masyarkat Bali.

Gerindra merupakan partai dengan platform, Nasionalis - Kerakyatan. Dalam upaya untuk menunjukkan hal tersebut Gerindra akan selalu membela kepentingan rakyat demi menciptakan kesejahteraan hidup masyarakat banyak. Keberhasilan Gerindra dalam meningkatkan elektabilitas partai pada pemilu 2009, 2014 dan 2019 telah memberikan antuasiame publik yang begitu besar, Gerindra mampu menunjukkan eksistensi pada perhelatan politik tahunan di pilkada maupun tingkat legislatif, Gerindra juga mampu menampung aspirasi masyarakat mengenai isu isu perekonomian yang berlandasakan pariwisata sebagai sektor pengembangan bagi kemajuan masyarakat di Bali.

Gerindra juga mampu mencetak para kader dan anggota, yang mampu dan mengerti tujuan visi dan misi partai Gerindra yang berlandaskan Nasional Kerakyatan. Lewat para kader dan anggota - nya Gerindra sukses dalam membentuk para calon yang mampu bersaing dalam konteks perpolitikan di Bali. Dalam menata kembali komodifikasi politik di Bali, Gerindra juga berupaya melihat peta politik daerah mana saja di Bali sebagai nilai dan fokus kemenangan para calon yang diusung oleh Gerindra.

Berbicara mengenai implikasi Gerindra yang mampu memberikan potensi terhadap sektor pengembangan politik, sosial maupun hukum, 11 tahun kontribusi tersebut dibangun oleh Gerindra untuk mentransformasikan tingkat kepercayaan masyarakat terhadap keberlangsungan partai Gerindra di Bali, baik di tingkat kota dan daerah kabupaten provinsi.

\section{REFERENSI}

Arjawa, S. et al., (2019). "Laporan Riset Kepemiluan 2019 Partisipasi Pemilih Provinsi Bali." https://journal.kpu.go.id/index.php/ERE/article/download/110/26/ (akses 18 Februari 2021).

Benyamin, M, I. \& Sudibya, K, P. (2019). “Analisis Kontekstualitas Komunikasi Politik Pemilihan Umum Presiden Republik Indonesia Tahun 2019 Dari Prespektif Hukum Tata Negara”. https://ojs.unud.ac.id/index.php/Kerthanegara/article/download/45964/27846/ (akses 20 Februari 2021).

Budianto, H. (2019). Kontestasi Politik Dalam Ruang Media. Jl. Tambara Raya No. 23 Rawamangun Jakarta: Prenada Media.

Gito, T. et al., (2013) Peran Komisi Pemilihan Umum Daerah (KPUD) Dalam Meningkatkan Partisipasi Politik Masyarakat (Studi di Kabupaten Bolaang Monggondow Utara). Jurnal Politico, 2 (1).

Hutapea, B. (2015). Dinamika Hukum Pemilihan Kepala Daerah di Indoensia. Jurnal RechtsVinding, 4 (1).

Kacung, M. (1993). Jurnal Ilmu Politik 13 : Dinamika Konflik di Partai Demokrasi Indonesia. Jakarta: PT. Gramedia Pustaka Utama.

Martini, R. (2012). Birokrasi dan Politik. Semarang: UPT Undip Press Semarang. Nico, O, A. et al., (2018). "Legitimasi Partai Politik Gerindra (Modal dan Struktur Peluang Gerindra Merebut Legitimasi Parlemen).” https://core.ac.uk/download/pdf/267944794.pdf (akses 17 Februari 2021). 
Nurdiansyah, F. (2018). Marketing Politik DPP Partai Gerindra Pada Pemilu Legislatif 2014. Jurnal Ilmu Politik Politika, 9 (1).

Nurhanisah, Y \& Putra, M, I, D., (2019). "Mengenal Sistem Pemilihan Umum di Dunia." https://indonesiabaik.id/mengenal-sistem-pemilihan-umum-di-dunia (akses 12 Maret 2020).

Razaqtiar, A, Z. (2016). Peran Partai Politik Dalam Pemilihan Kepala Daerah: Studi Upaya Partai Golkar dalam Memenangkan Pasangan Calon Juliayatmono Rohadi di Pemilihan Kepala Daerah Kabupaten Karanganyar 2013. Jurnal Politik Muda, 5 (3).

Rudy, T, M. (1993). Pengantar Ilmu Politik : Wawasan Pemikiran dan Kegunaannya. PT. Eresco Anggota IKAPI.

Surywan, I, N. (2012). Sisi di Balik Bali, Politik Identitas, Kekerasan, dan Interaksi Global. Bali: Udayana University Press. 